\title{
Significance of Deformation Microstructures of Mineral Grains in the Study of Diffusivity and Permeability in Intact Granitoids
}

\author{
Kazuo KOSAKA* and Takato TAKEMURA **
}

\begin{abstract}
Microscopic observation of intact granitoids reveals that different kinds of deformation microstructures within mineral grains result from various processes ; deformation microstructures due to microcracking, microfaulting, microfolding, recovery and recrystallization. Some samples of intact granitoids exhibit only the undulose extinctions of quartz, plagioclase and biotite, while the others show abundant deformation microstructures, indicating that they contain many submicron-sized apertures in them. These deformation microstructures may be important as a possible cause of diffusivity and permeability of intact granitoids.

Water pathways within intact granitoids are detected in an experiment based on the capillarity of a $\mathrm{KMnO}_{4}$ solution. The EPMA images show that $\mathrm{MnO}_{2}$ is present on the polished surfaces of orthoclase, plagioclase and biotite grains after the experiment. $\mathrm{MnO}_{2}$ occurs in three ways : on grain-boundaries and/or intragranular cracks, in clustered submicron-sized pores, and dispersed on plagioclase and biotite grains. These modes of occurrence suggest that water pathways in intact granitoids are not only grain-boundaries and/or intragranular microcracks, but may also be mineral grains themselves that are permeated with submicron-sized apertures possibly having formed in deformation microstructures.

It follows that deformation microstructures should be most apparent at sites where abundant submicron-sized apertures are present. There are differences of deformation grade even in intact granitoids. This means that some intact granitoids include relatively few deformation microstructures, whereas others include many deformation microstructures. Since deformation microstructures are possible pathways for water, it is very likely that the diffusivity and permeability of a granitoid sample correlates with the nature and abundance of its included deformation microstructures. These microscopic observations and experiment suggest that deformation microstructures, as well as microcracks, should be studied much more thoroughly with regard to the diffusivity and permeability of intact granitoids.
\end{abstract}

Key words : deformation texture, diffusivity, permeability, granitoid

\section{Introduction}

Microcracks in the mineral grains of intact granitoids have been intensively studied from the viewpoint of material transport properties such as diffusivity and permeability. This interest arose because increases in diffusivity or permeability of intact granitoids are mainly attributed to microcracks that originate from tectonic, thermal, and other stresses. In addition to the microcracks seen under a microscope, various

* 日本大学文理学部地球システム科学科 Department of Geosystem Sciences, Nihon University E-mail: kosaka@chs.nihon-u.ac.jp (会員)

** 日本大学大学院総合基礎科学研究科 Graduate School of Integrated Basic Sciences, Nihon University（会員） kinds of submicron-sized apertures, including grain boundaries and pores as well as submicronsized microcracks, are also important as water pathways in intact granitoids $^{1) \sim 3)}$. The deformation microstructures of mineral grains exhibit various kinds of submicron-sized apertures, which may be important as possible causes of diffusivity and permeability, especially for intact granitoids with very few microcracks or with low permeabilities around $10^{-6}$ to $10^{-12} \mathrm{~m} / \mathrm{s}^{4}$. This paper describes a series of deformation microstructures of the mineral grains in intact granitoids, and also presents the result of experiment on the permeability of intact granitoids. These microscopic observations and experiment suggest that deformation microstructures, as well 
Table 1 Deformation textures in intact granitoids

Deformation textures in five kinds of mineral grains (left-side column) are arranged according to their types (uppermost raw)

\begin{tabular}{|c|c|c|c|c|c|}
\hline & Microcrack & Microfault & Microfold & $\begin{array}{c}\text { Undulose } \\
\text { extinction }\end{array}$ & Subgrain \\
\hline Quartz & $\begin{array}{l}\text { Microcrack } \\
\text { - irregular } \\
\text { - subparallel } \\
\text { - en echelon }\end{array}$ & & & $\begin{array}{l}\text { Undulose extinction } \\
\text { - simple } \\
\text { - irregular } \\
\text { - banded }\end{array}$ & $\begin{array}{l}\text { Subgrain } \\
\text { - isolated } \\
\text { - clustered } \\
\text { - twig-like }\end{array}$ \\
\hline Plagioclase & $\begin{array}{l}\text { Microcrack } \\
\text { - irregular } \\
\text { - subparal lel }\end{array}$ & $\begin{array}{l}\text { Microfault } \\
\text { Slipped cleavage } \\
\text { Slipped twin }\end{array}$ & $\begin{array}{l}\text { Bent twins } \\
\text { Kink band }\end{array}$ & $\begin{array}{l}\text { Undulose extinction } \\
\text { - simple } \\
\text { - irregular } \\
\text { - banded }\end{array}$ & $\begin{array}{l}\text { Subgrain } \\
\text { - isolated }\end{array}$ \\
\hline Micas & $\begin{array}{l}\text { Microcrack } \\
\text { - irregular } \\
\text { Pseudostylolite } \\
\text { Cloven cleavage }\end{array}$ & $\begin{array}{l}\text { Microfault } \\
\text { Slipped cleavage }\end{array}$ & $\begin{array}{l}\text { Bent cleavages } \\
\text { Kink band } \\
\text { Cusped cleavages } \\
\text { En echelon wrinkles }\end{array}$ & $\begin{array}{l}\text { Undulose extinction } \\
\text { - simple }\end{array}$ & \\
\hline Orthoclase & $\begin{array}{l}\text { Microcrack } \\
\text { - irregular }\end{array}$ & Microfault & & $\begin{array}{l}\text { Undulose extinction } \\
\text { - simple } \\
\text { - irregular }\end{array}$ & \\
\hline Amphiboles & $\begin{array}{l}\text { Microcrack } \\
\text { - irregular }\end{array}$ & & & Undulose extinction & \\
\hline
\end{tabular}

as microcracks, should be studied much more thoroughly with regard to the diffusivity and permeability of intact granitoids.

\section{Deformation textures of mineral grains}

Even for intact granitoids, some constituent mineral grains exhibit deformation microstructures to a greater or lesser degree. Microscopic observation reveals that different kinds of deformation textures result from various processes, as follows (Table 1).

\subsection{Deformation textures due to various proc- esses}

Textures due to microcracking: Microcracks generally form in quartz, plagioclase, micas, orthoclase and amphiboles and they may have irregular, subparallel, or en echelon patterns (see the review by $\mathrm{KRANZ}^{5}$ ). Irregular microcracks generally form in all of these five kinds of mineral grains, although subparallel microcracks preferentially form in quartz and plagioclase ${ }^{6}$. En echelon microcracks with lengths less than about 10 ${ }^{-4} \mathrm{~m}$ mainly form in quartz grains ${ }^{6), 7)}$. Pseudostylolites and cloven cleavages form in biotite grains ${ }^{8)}$. Pseudostylolites are a deformation texture resembling stylolites in limestones (Photo 1a), and cloven cleavages refer to cloven and open cleavages that are generally filled with minerals such as chlorite or quartz (Photo 1-b).

Textures due to microfaulting: Microfaults generally form in plagioclase, biotite and orthoclase
(Photo 1-c), but rarely in quartz and amphiboles of intact granitoids ${ }^{8)}$. Slipped cleavages form in plagioclase and biotite ${ }^{8), 9)}$. Slipped twins form in plagioclase $^{8)}$ (Photo 1-d).

Textures due to microfolding: Bent twins generally form in plagioclase and bent cleavages generally form in biotite ${ }^{8,10), 11)}$ (Photo $1^{-} \mathrm{e}$ ). Kink bands also generally form in plagioclase and biotite, as described in many literatures ${ }^{9,12), 13)}$. Cusped cleavages and en echelon wrinkles form in biotite grains $^{8)}$ (Photo $1-\mathrm{f},-\mathrm{g}$ ).

Textures due to undulose extinction: Undulose extinction (i.e., undulotary or wavy extinction) occurs generally as simple, irregular or banded patterns $^{8), 14)}$. Quartz and plagioclase grains exhibit these three patterns of undulose extinction, while micas show a simple pattern of undulose extinction or bent cleavages. Orthoclase generally exhibits simple or irregular undulose extinctions, but amphiboles scarcely show undulose extinctions in intact granitoids.

Textures due to recovery and recrystallization: Subgrains generally form in quartz as isolated, clustered or twig-like patterns (Photo $1-\mathrm{h}$ ). Subgrains occasionally form in plagioclase, but generally do not form in biotite, orthoclase or amphiboles in intact granitoids.

\subsection{Abundances of deformation textures}

Figure 1 shows the relative abundances of deformation textures in two samples of intact granitoids from central Japan; one from the 

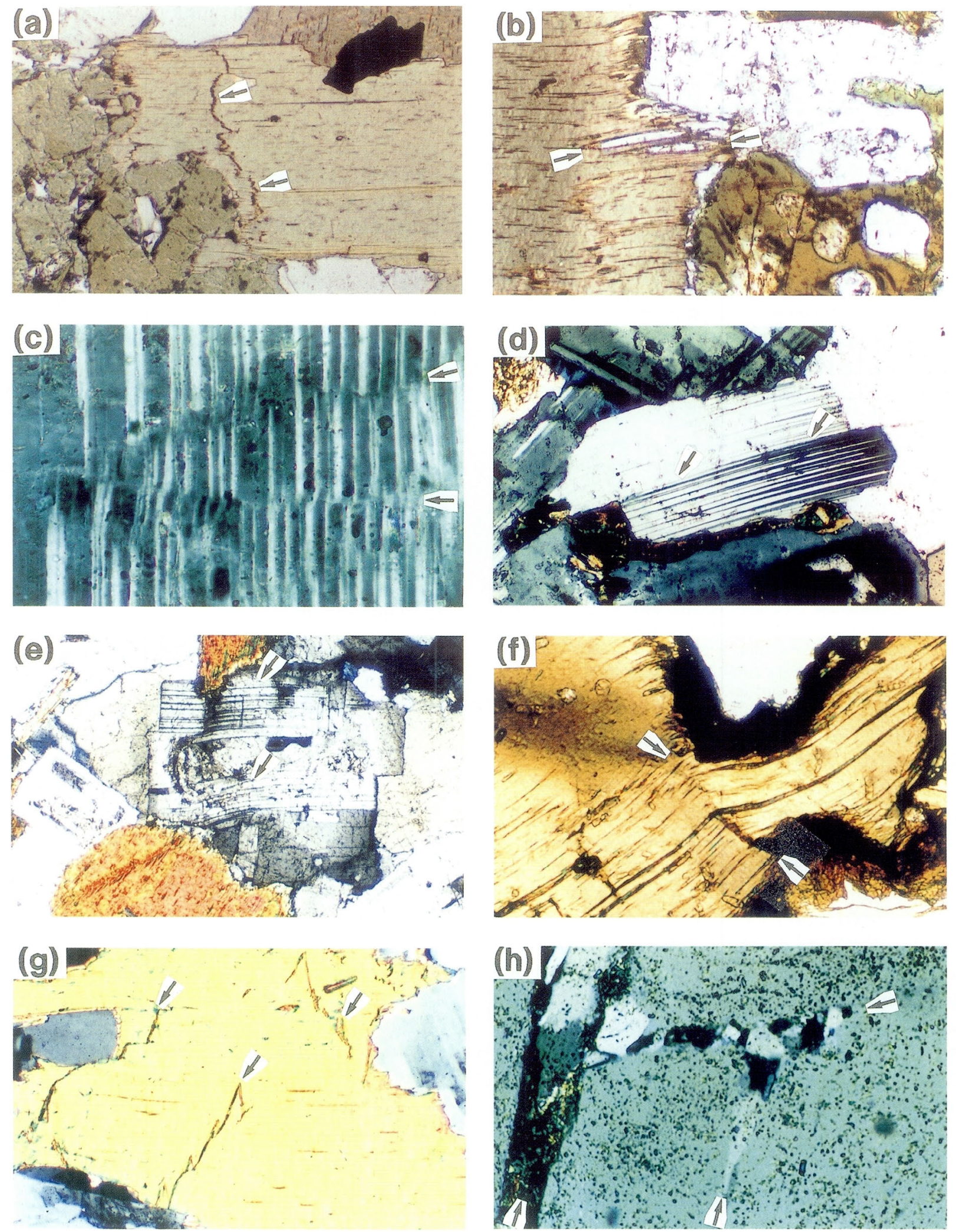

$0.5 \mathrm{~mm}$

for (a), (b), (c), (d)), (g) and (h)

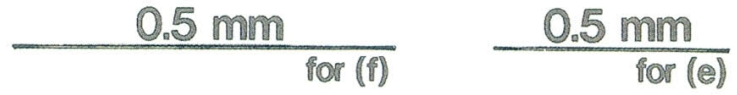

Photo 1 Photomicrographs of defomation textures in intact granitoids

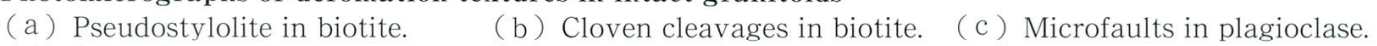

(d) Slipped twin in plagioclase. (e ) Bent twins in plagioclase.

(f) Cusped cleavages in biotite.

(g) En echelon wrinkles in biotite. (h) Subgrain twig in quartz. 


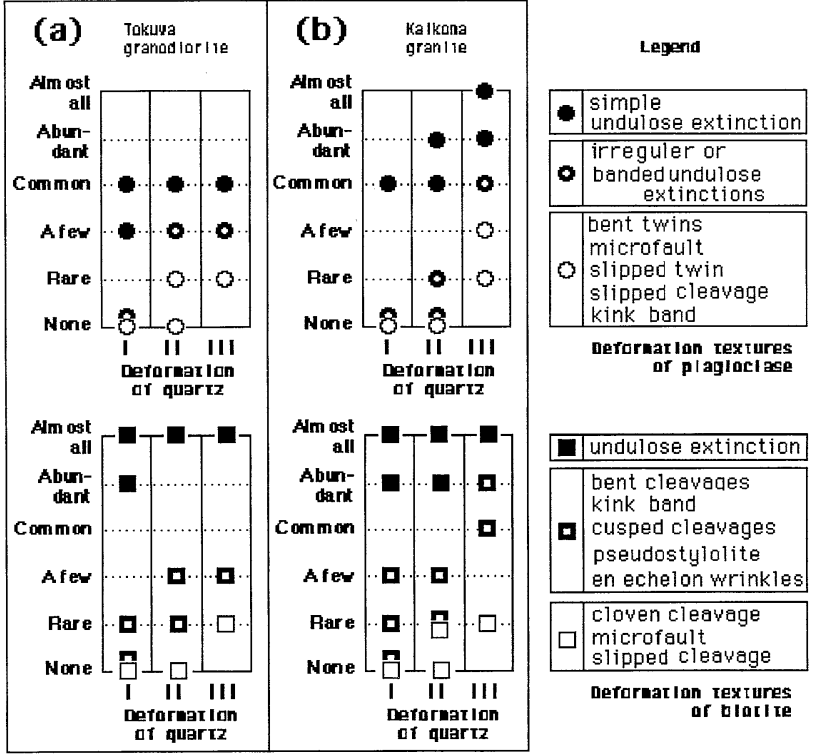

Figure 1 Relative abuncances of deformation textures based on the deformation of quartz

(a) The result of microscopic observation of more than 150 thin sections. (b) The result of microscopic observation of about 30 thin sections. Almost all : Almost all grains show the corresponding deformation texture. Abundant : About three quarters of grains show the corresponding deformation texture. Common: About one half of grains show the corresponding deformation texture. A few : A few grains show the corresponding deformation texture. Rare : The corresponding texture is formed in only few grains. None : No grains show the corresponding deformation texture.

Miocene Tokuwa granodiorite (Fig. 1-a) and the other from the Miocene Kaikoma granite ${ }^{15)}$ (Fig. 1 -b). In this figure, samples are classified as I, II or III, based on the deformation textures seen in quartz. I , II and III are the respective classes of samples in which [undulose extinction], [undulose extinction + isolated subgrains], and [undulose extinction + isolated subgrains + clustered subgrains] occur. Figure 1 shows that class I samples exhibit only the undulose extinctions of quartz, plagioclase and biotite. Class III samples show abundant deformation textures, indicating that they contain many deformation microstructures, even though all samples are intact and appear as non-deformed granitoids to the naked eye.

\section{Water pathways within intact granitoids}

Water pathways within intact granitoids may be detected in an experiment based on the capillarity of a $\mathrm{KMnO}_{4}$ solution $^{3)}$. The samples were shaped into cylindrical form of $25 \mathrm{~mm}$ in diameter and $12 \mathrm{~mm}$ height. The top and bottom faces of cylinders were polished with $1 \mu \mathrm{m}$-diamond paste, and the surrounding sides of cylinders were coated with epoxy resin. The lower halves of cylinders was sunk into $\mathrm{KMnO}_{4}$ solution of $0.2 \mathrm{~mol} / 1$ for two weeks inside a vacant box. After the capillarity experiment, the samples were dried for a few days at $110^{\circ} \mathrm{C}$. $\mathrm{MnO}_{4}^{-}$deoxidizes into $\mathrm{MnO}_{2}$, which sticks to the walls of apertures and is reddish purple in color. The prepolished surfaces of intact granitoids are stained by the reddish purple $\mathrm{MnO}_{2}$, which is then detected with an electron probe microanalyzer (EPMA). Figure 2 shows the result of experiment with Tokuwa granodiorite. The EPMA images show that $\mathrm{MnO}_{2}$ is present on the polished surfaces of orthoclase, plagioclase and biotite grains. $\mathrm{MnO}_{2}$ occurs in three ways : on grain-boundaries and / or intragranular cracks, in clustered submicron-sized pores, and dispersed on plagioclase and biotite grains. These modes of occurrence suggest that water pathways in intact granitoids are not only grain-boundaries and/or intragranular microcracks, but may also be mineral grains themselves that are permeated with submicron-sized apertures.

\section{Discussion}

Deformation microstructures include various kinds of submicron-sized apertures. It is well known that microcracking and microfaulting produce a variety of apertures in quartz, feldspars and micas ${ }^{16)}$. It is now known that similar apertures are caused by microfolding. SEIFERT and VERPLOEG ${ }^{17)}$ reported a continuous series of small connected microcracks less than $10^{-6} \mathrm{~m}$ wide and less than $10^{-5} \mathrm{~m}$ long occurring along kink band boundaries in albite. Similar features have been reported elsewhere ${ }^{16)}$. Undulose extinction, especially banded undulose extinction, is also indicative of submicron-sized apertures. TULLIS and YUND ${ }^{18}$ noted that the optical undulose extinctions of quartz and feldspars may be manifestations of microcrack arrays or submicroscopic gouge zones $10^{-6} \mathrm{~m}$ wide and $10^{-5} \mathrm{~m}$ long.

Various kinds and sizes of apertures, including submicron-sized cracks, pores, and grain boundaries, have recently been studied by employing blue resins ${ }^{19)}$, fluorescent materials ${ }^{20), 21)}$, replica films ${ }^{22)}$, and other laboratory experiments ${ }^{1) \sim 33,23)}$. These studies have statistically delineated features, such as the distribution of apertures by their lengths and widths, which may not be apparent under a microscope. The spatial distribution patterns of apertures, as well as their connectivity, are also important features when studying permeability ${ }^{24}$. The sizes of such aper- 

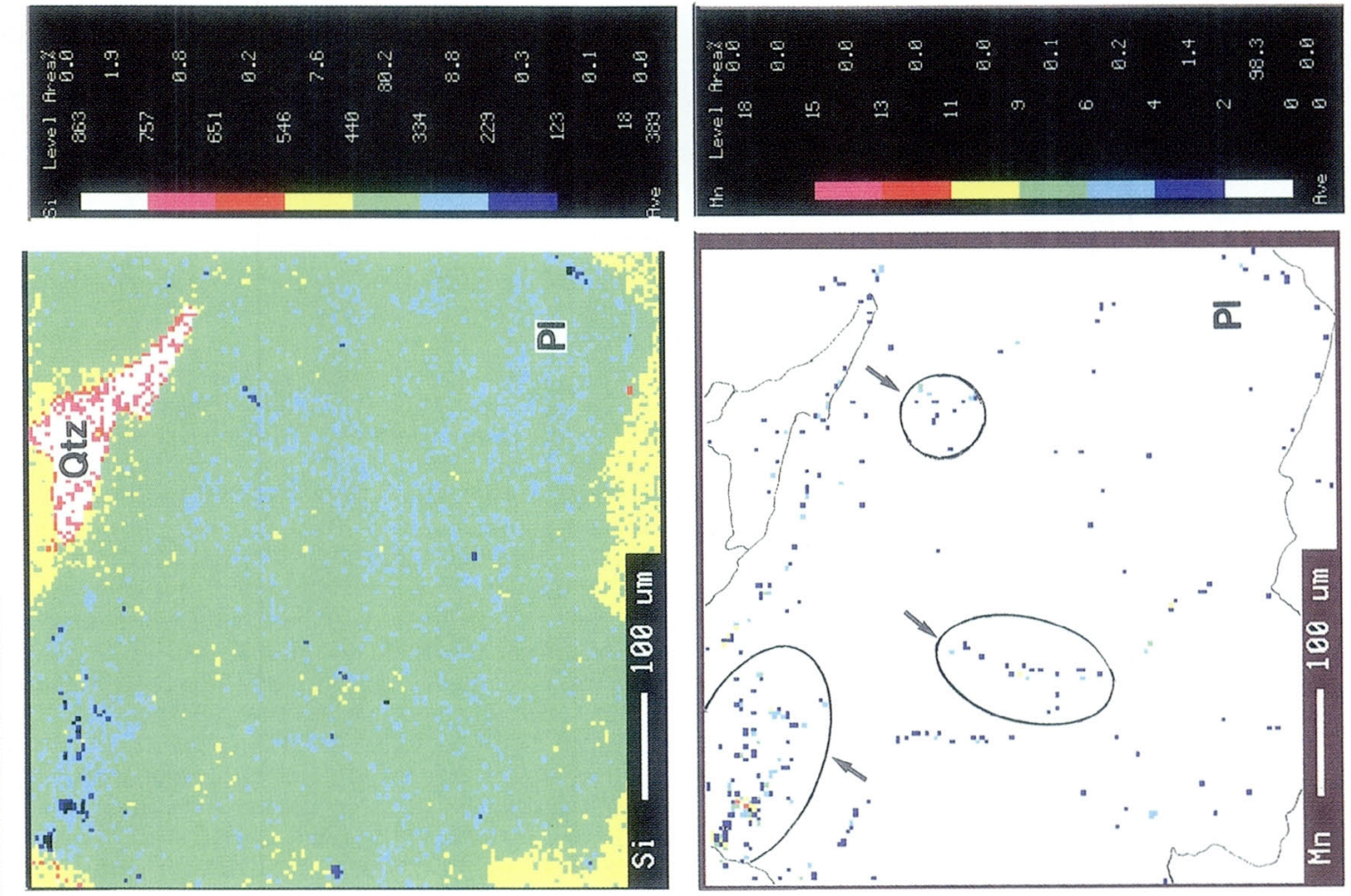

\section{을}
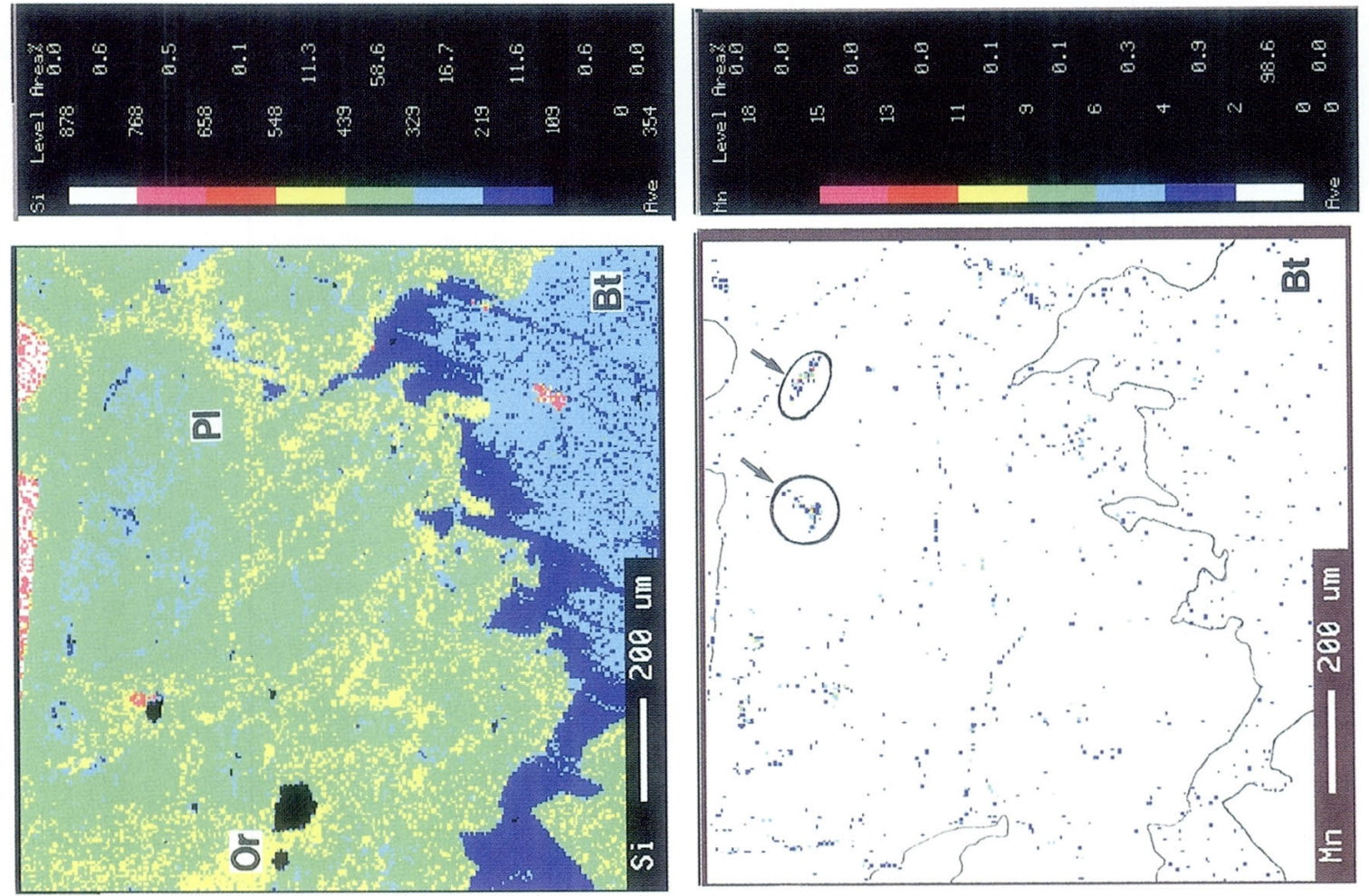

(1)

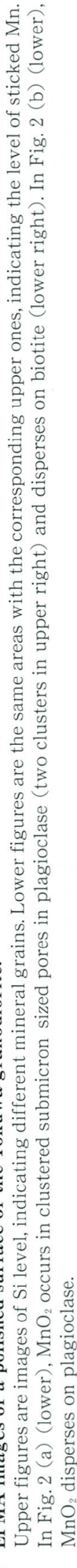

党 
tures range from microscopic to submicroscopic, or $10^{-6}$ to $10^{-8} \mathrm{~m}^{33,25)}$.

It follows that deformation microstructures should be most apparent at sites where abundant submicron-sized apertures are present. There are differences of deformation grade even in intact granitoids $^{8), 14)}$. This means that some intact granitoids include relatively few deformation microstructures, whereas others include so many deformation microstructures that their diffusivity or permeability is increased. Since deformation microstructures are possible pathways for water, it is very likely that the diffusivity and permeability of a granitoid sample correlates with the nature and abundance of its included deformation microstructures. It is also noteworthy that many deformation textures in Photo 1 are connected with grain boundaries.

\section{Summary}

Various kinds of deformation microstructures tend to form in constituent mineral grains even within intact granitoids. Although their abundances differ from sample to sample, submicron-sized apertures can form within such microstructures and are the possible cause of the diffusivity and permeability of intact granitoids. The deformation microstructures of intact granitoids need to be more intensively studied with regard to material transport properties. This is especially true for intact granitoids that have few microcracks or low permeability.

\section{References}

1) KATSUBE, T. J. (1981): Pore structure and pore parameters that control the radionuclide transport in crystalline rocks, Prof. Tech. Prog. Int. Powder and Bulk Solid Handling and Processing, pp. 394-409.

2) WADDEN,M. M.and KATSUBE,T. J.(1982): Radionuclide diffusion rates in igneous crystalline rocks, Chem. Goel., Vol.36, pp. 191-214.

3 ) SUZUKI, T., NAKASHIMA, S., NAGANO, T. and KITA, H. (1989) : Micropore distributions in granite as material migration pathways, Mining Geol., Vol.39, pp. 349-354. *

4) UMEDA, K., YANAGIZAWA, K. and YONEDA, S. (1995): Data-base of permeability of rock mass in Japan, Jour. Groundwater Hydrology, Vol.37, pp. 69-77. ${ }^{*}$

5 ) KRANZ, R. L. (1983) : Microcracks in rocks: a review, Tectonophys., Vol.100, pp. 449-480.

6 ) KOSAKA, K., TAKIZAWA, S. and CHIBA, M. (1992): Microscopic deformations of low-strained Neogene granitoids and their use for tectonics study, Proc. Inst. Nt. Sci., Nihon Univ., No.27, pp. 57-61.*

7 ) KOSAKA, K. (1980) : Fault-related fabrics of granitic rocks, Jour. Fac. Sci., Univ. Tokyo, Sec. II, Vol.20, pp. 77-115.
8 ) KOSAKA, K., SHIMIZU, M. and TAKIZAWA, S. (1999): Late- to post-magmatic deformation of the Miocene Tokuwa granodiorite, central Japan, Resource Geol. (in press)

9 ) PASSCHIER, C. W. and TROUW, R. A. J. (1996) : Microtectonics, Springer, Berlin, 289p.

10) TAKAGI, H. (1984) : Mylonitic rocks along the Median Tectonic Line in Takato-Ichinose area, Nagano Prefecture, Jour. Geol. Soc. Japan, Vol.90, pp. 81-100. ${ }^{*}$

11) PRYER, L. L. (1993) : Microstructures in feldspars from a major crustal thrust zone: the Grenville Front, Ontario, Canada, Jour. Struct. Geol., Vol.15, pp. 21-36.

12) HORZ, F. (1970): Static and dynamic origin of kink bands in mica, J. Geophys. Res., Vol.76, pp. 965-997.

13) KANAORI, Y. (1990): Active faults and microstructures of granitic rocks, Jour. Res. Group for Tectonics and Struct. Geol., no. 35, pp. 45-49.*

14) KOSAKA, K. and SHIMIZU, M. (1994): Deformation zoning of the Tokuwa Batholith, central Japan, Jour. Res. Group for Tectonics and Struct. Geol., No.40, pp. 160-161. **

15) KOSAKA, K. and TAKIZAWA, S. (1992): Texture change of granite associated with mylonite formation: an exmaple from the Kaikoma granite near the Itoigawa Shizuoka Tectonic Line, central Japan, Gekkan Chikyu (Earth Monthly), Vol.14, pp. 209-214. **

16) DEBAT, P., SOULA, J.C., KUBIN, L. and VIDAL, J.L. (1978) : Optical studies of natural deformation microstructures in feldspars (gneiss and pegmatites from Occitania, southern France), Lithos, Vol.11, pp. 133-145.

17) SEIFERT, K. and VERPLOEG, A. J. (1977) : Deformational characteristics of experimentally deformed Adirondack anorthosite, Can. Jour. Earth Sci. Vol.14, pp. 2706-2717.

18) TULLIS, J. and YUND, R. A. (1977) : Experimental deformation of dry Westerly granite, J. Geophys. Res., Vol.82, pp. 5705-5718.

19) TAKAHASHI, M., XUE, Z., OOWADA, A. and ISHIJIMA, Y. (1992): On the study of interconnected pore network using a blue dyed epoxy impregnated thin section, Jour. Japan Soc. Eng. Geol., Vol.33, pp. 294-306.

20) NISHIYAMA, T., KUSUDA, H. and SAITO, T. (1992) : A few remarks on examination of cavities or microcracks produced in rocks using a fluorescent substance, Jour. Japan Soc. Eng. Geol., Vol.33, pp. 17-22.*

21) KUSUDA, H. and NISHIYAMA, T. (1994): Extraction and evaluation of microcracks in rocks by methods of image processing-examination of microcracks in weathered granite and andesite fractured by uniaxial compression test-, Jour. Japan Soc. Eng. Geol., Vol.34, pp. 292-299.*

22) SUZUKI, K. and TAKAHASHI, M. (1994):A visualizing method of pores and cracks using filmy replica system, Jour. Japan Soc. Eng. Geol., Vol.35, pp. 77-78.*

23) LIN, W., TAKAHASHI, M and SUGITA, N. (1995) : Change of microcrack widths induced by temperature increase in Inada granite, Jour. Japan Soc. Eng. Geol., Vol.36, pp. 300 304.

24) TAKAHASHI, M., HIRATA, A. and H. KOIDE (1990) : Effect of confining pressure and pore pressure on permeability of Inada granite, Jour. Japan Soc. Eng. Geol., Vol.31, pp. 105-114.

25) NAKASHIMA, S. (1995) : Fractal analyses of fractures, grain boundaries and pore structures of granite and its relation to material transport and rheology, Jour. Min. Soc. Japan, Vol.24, pp. 125-130.

\section{Appendix}

* : in Japanese with English abstract, **: in Japanese. (1999年 3 月17日受付，1999年 5 月12日受理) 
応用地質，第 40巻，第 3 号，159-165頁，1999

\title{
インタクトな花崗岩類の拡散性・透水性研究における 鉱物粒内変形微小構造の意義
}

\author{
小坂和夫・竹村貴人
}

要 旨

インタクトな花崗岩類の場合でも, 構成鉱物粒内には多かれ少なかれ変形微小構造が形成されている.それらの微小变形構造 は, 微小割れ目形成, 微小断層, 微小褶曲, 回復, 再結晶という過程を通じて形成される.これらの微小変形構造の中のサブミ クロンサイズの割れ目やガウジはインタクトな花崗岩類の拡散や透水の通路になっている. 実際に, 過マンガン酸カリウム水溶 液を用いた毛管実験によって，いわゆるマイクロクラックやグレインバウンダリー以外の鉱物粒内にも水溶液の通った痕跡が EPMAにより確認される. 変形微小構造内にサブミクロンサイズの割れ目やガウジが多く作られていることから判断して, イン タクトでマイクロクラックの少ない花崗岩類の拡散や透水を評価する上で, 偏光顕微鏡による変形微小構造の種類や量の評価は 重要な視点となろう。

キーワード : 変形組織, 拡散, 透水, 花崗岩 